\title{
GRAIN SIZE ANALYSIS OF BEACH SEDIMENT ALONG THE BARRIER BAR LAGOON COASTAL SYSTEM, LAGOS, NIGERIA; ITS IMPLICATION ON COASTAL EROSION
}

\author{
RABIU ABDULKARIM, E. A. AKINNIGBAgBE, D. O. IMO, M. T. IMHANSOlOEVA, V. 0. \\ ANIEBONE, M. P. IBITOLA, B. R. FALEYE, O. SHONDE AND Y. J. APPIA
}

(Received 18 November 2013; Revision Accepted 4 February 2013)

\begin{abstract}
Beach sediments were collected from four selected beaches along the barrier bar lagoon coastal system Lagos Nigeria namely Badagry, Takwa, Alpha and Eleko beaches. The sediments were texturally analyzed in order to determine the statistical parameters of their grain size distribution. The result shows that Badagry and Alpha beach sands are medium grained with average mean values of $(1.10 \Phi$ and $1.14 \Phi$ respectively). Eleko beach sediment is coarsely grained with an average mean value of $(0.56 \Phi)$ while Takwa Bay beach sediment is fine grained and very well sorted with an average mean value of $(2.25 \Phi$.). This suggest that Eleko beach sediment being coarse grained is deposited in a high energy condition hence less vulnerable to erosion compared to Takwa bay beach sediment which is fine grained and deposited in low energy condition hence more vulnerable to erosion. Alpha and Badagry beach sediment are medium grain and deposited in a moderate energy condition hence more stable to erosional forces than Takwa bay beach sediment. The grain size and amount of sand on a beach depends on wave energy and geological sensitivity of the sediments to the forces of erosion
\end{abstract}

KEYWORDS: Barrier Bar Lagoon, Beach Sediments, Grain Size Distribution, Erosion.

\section{INTRODUCTION}

Coastal erosion is a natural phenomenon which has always existed and has contributed to the shaping of coastal landscapes. Coastal erosion is the main process which provides sediment to the coastal system including beaches, dunes, reef, mud flat and marshes. In turn coastal system provides a wide range of functions including absorption of wave energy and silting for recreational activities. However migration of human population towards the coastal zone has turned coastal erosion into problem of growing concern. The problem of coastal erosion along the barrier lagoon coastal system is exemplified by the erosion problem along the Victoria beach in Lagos. The problems most commonly encountered include collapse of the dune system as a result of storm event which result in flooding of the hinterland, destabilization of socio-economic activities and degradation of the environment. Grain size characteristics are reliable in understanding the provenance, transport mechanism and depositional environment of sediments

An annual an annual erosion rate of 25 to $30 \mathrm{~m}$ has been reported at Victoria beach in Lagos. Among the natural causes of erosion along the barrier lagoon coastal system are vulnerable sediment characteristics, low lying coastal topography, intense wave and tide nature of shelf width topography and the occurrence of offshore canyons. Beach sediments along the barrier lagoon coast range from fine to coarse sand. The sediment particles are transported by stress due to motion of fluid which are carried in suspension and

Rabiu abdulkarim, Nigeria Institute for Oceanography and Marine Research, 3 Wilmot Point Road, off Ahmadu Bello Way Victoria Island, Lagos, Nigeria.

E. A. Akinnigbagbe, Nigeria Institute for Oceanography and Marine Research, 3 Wilmot Point Road, off Ahmadu Bello Way Victoria Island, Lagos, Nigeria.

D. O. Imo, Nigeria Institute for Oceanography and Marine Research, 3 Wilmot Point Road, off Ahmadu Bello Way Victoria Island, Lagos, Nigeria.

M. T. Imhansoloeva, Nigeria Institute for Oceanography and Marine Research, 3 Wilmot Point Road, off Ahmadu Bello Way Victoria Island, Lagos, Nigeria.

V. O. Aniebone, Nigeria Institute for Oceanography and Marine Research, 3 Wilmot Point Road, off Ahmadu Bello Way Victoria Island, Lagos, Nigeria.

M. P. Ibitola, Nigeria Institute for Oceanography and Marine Research, 3 Wilmot Point Road, off Ahmadu Bello Way Victoria Island, Lagos, Nigeria.

B. R. Faleye, Nigeria Institute for Oceanography and Marine Research, 3 Wilmot Point Road, off Ahmadu Bello Way Victoria Island, Lagos, Nigeria.

O. Shonde, Nigeria Institute for Oceanography and Marine Research, 3 Wilmot Point Road, off Ahmadu Bello Way Victoria Island, Lagos, Nigeria.

Y. J. Appia, Nigeria Institute for Oceanography and Marine Research, 3 Wilmot Point Road, off Ahmadu Bello Way Victoria Island, Lagos, Nigeria. 
eroded away by low energy wave, longshore or tidal current. The amount of sediment carried by longshore or tidal currents depends on the grain size and the velocity of the current. Beach sediments along the barrier complex show wide variation in textural characteristics. The sediment compositions are affected by wave/tidal action, littoral current and the petrographical compositions of the shore; hence the grain size distribution of beach sand is a function of the hydrodynamic conditions. The sediment distributions along the beaches are hence a result of complex interaction between sediment source, wave energy level and the general offshore slope on which the beach is constructed. The intensity of the wave action in the littoral zone generally redeposits and sort materials of all grain sizes. Thus, the composition of beach sediment is not affected only by wave action but depends largely on the amount of clastic materials supplied to the coast. This study was carried out along the active beaches of the Barrier Bar complex; (Badagry on the western, Alpha, Takwa and Eleko on the eastern end. The aim is to determine the grain size distribution with a view to understanding the geological sensitivity of the sediment to the forces of erosion. Knowledge of these characteristics is important in understanding the fundamental principles of shoreline dynamics necessary for the management of erosion along the barrier lagoon coastal system in Nigeria.

\section{THE STUDY AREA}

The study area is located on the Barrier Lagoon (Fig. 1). The Barrier/Lagoon coastal system extends eastward for about $200 \mathrm{~km}$ from the Nigeria/Benin Republic border to the western limit of the transgressive mud coast .Its general evolution and morphology has largely been determined by coastal dynamics and the deposition of fluvial sediments. The beaches of the barrier bar complex are erosive, probably due to lack of Exoreic Rivers, which would have compensated for the sand lost from the action of longshore current. The Barrier Lagoon complex is backed by the Badagry Creek, the Lagos Lagoon, Lekki Lagoon and numerous other creeks whose only connection to the sea is through the commodore channel in Lagos. The Barrier Lagoon coastal system consists of narrow beach ridges, which are aligned parallel to the coast. The origin of the barrier bar complex has been postulated by several workers. Benard (1962) stated that movement of sand on the front of a notched sector of the coast lead to the evolution of the lagoon. He suggested that sands deposited at appropriate locations filled the notches, reducing and shortening the coastline and resulting in a straight barrier beach which continues to grow in length. (Allen 1965) viewed the formation of barrier islands in terms of coast wide progradation resulting from longshore drift. Webb (1958) and Hoyt (1967) suggested the submergence of a dune or beach ridge to form the barrier island Lagoon. Ibe and Awosika 1984 and Ibe 1998 postulated that sediments constituting the barrier Islands are of terrigenous origin of Benin formation, laid down through the agent of Rivers during the late Wisconsin low stand of the sea level (2000Bp). These sediments were later reworked and swept landward, away from the River Mouths by wave action during the ensuring marine transgression to form offshore bar

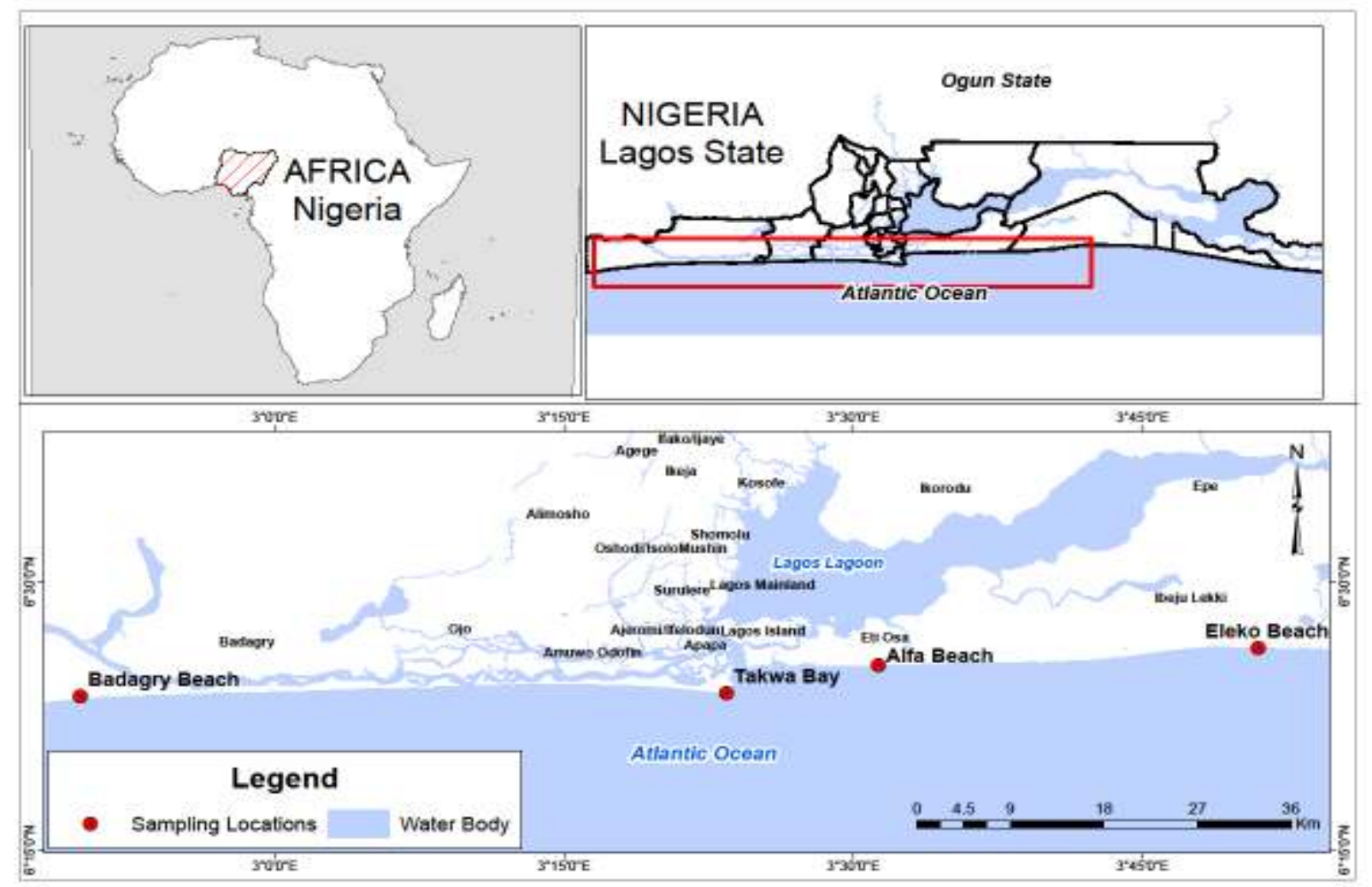

Fig 1: Beach Sediment Sampling Stations on the Barrier Lagoon; Nigeria. 


\section{METHODOLOGY}

Beach sediment samples were collected from four selected beaches, this includes: Badagry, Alpha, Takwa bay and Eleko beach. Eight samples were collected from each beach making a total of thirty 32 samples. The samples were collected from shallow trenches at 100 meters interval; using a plastic jar to ensure a uniform sampling depth of $5 \mathrm{~cm}$. Coordinates of the various sampling stations were taken using the global position system (GPS). Two samples representing the berm and fore shore were collected per profile. In the laboratory, 70 grams of each sample was oven dried at $50^{\circ} \mathrm{C}$ in order to remove their moisture content. The dried and weighed sediments were transferred carefully to the uppermost (coarsest) of a stacked series of graded sand sieves, sieves were gently brushed of all material from the container using a fine sieve brush. A $62 \mu \mathrm{m}$ sieve was placed at the bottom of the stack of sieves and care was taken by using a pan below the finest sieve to catch the last of any fine material which may still pass. The stacked column of sieves was now transferred to a Rotap sieve shaker for a period 10-15 minutes. The fraction of samples retained on each sieve was emptied on to a sheet of glazed paper and grains lodged in the sieve were removed with a sieve brush.
The fractions were then transferred to a pre weighed dish for weighing. This was done for all the sieves till the material passing through the last $(62 \mu \mathrm{m})$ sieve and that retained in the pan were also recorded. A graph of cumulative weight percent against sieve size was plotted. And from the cumulative frequency curve obtained grain size parameters such as average size (mean), spread of the sizes about the average (standard deviation) symmetry of preferential spread to one size of the average (skewness) and kurtosis or degree of concentration of the grains to the central size were determined.

\section{RESULTS AND DISCUSSION}

The statistical parameters of grain size distribution have been a major parameter in delineating the influence of deposional processes (Friedman, 1961; Folk, 1966). Generally, standard deviation and skewness are considered environmentally sensitive indicators while the mean is a reflection of the competence of the transport dynamic system. The results of the granulometric analysis of samples of Badagry, Takwa bay, Alpha and Eleko beaches are presented in table 1, 2, 3 and 4 . Figure 1 to 4 show the cumulative curve and individual particle size of each sample from which the grain size parameters were calculated.

Table 1: Granulometric Analysis of Badagry Beach Sediment

\begin{tabular}{|c|c|c|c|c|c|}
\hline Sample No & Mean & $\begin{array}{l}\text { Standard } \\
\text { deviation }\end{array}$ & Skewness & Kurtosis & Description \\
\hline $\mathrm{BD} 1 \mathrm{~A}(\mathrm{BM})$ & 1.28 & 0.57 & 0.17 & 1.29 & $\begin{array}{l}\text { Medium sand, Moderately well sorted, } \\
\text { Fine skewed, Leptokurtic. } \\
\text { Medium sand, Moderately well sorted, }\end{array}$ \\
\hline $\mathrm{BD} 1 \mathrm{~B}(\mathrm{WL})$ & 1.17 & 0.51 & 0.1 & 1.009 & $\begin{array}{l}\text { Fine skewed, Mesokurtic. } \\
\text { Medium sand, Moderately well sorted, }\end{array}$ \\
\hline $\mathrm{BD} 2 \mathrm{~A}(\mathrm{BM})$ & 1.1 & 0.57 & 0.18 & 1.06 & $\begin{array}{l}\text { Fine skewed, Mesokurtic. } \\
\text { Medium sand, Moderately well sorted, }\end{array}$ \\
\hline $\mathrm{BD} 2 \mathrm{~B}(\mathrm{WL})$ & 1.15 & 0.67 & 0.27 & 1.39 & $\begin{array}{l}\text { Fine skewed, Leptokurtic } \\
\text { Medium sand, Moderately well sorted, }\end{array}$ \\
\hline $\mathrm{BD} 3 \mathrm{~A}(\mathrm{BM})$ & 1.32 & 0.52 & 0.18 & 1.11 & $\begin{array}{l}\text { Fine skewed, Leptokurtic. } \\
\text { Medium sand, Well sorted, Coarse }\end{array}$ \\
\hline $\mathrm{BD} 3 \mathrm{~B}(\mathrm{WL})$ & 1.3 & 0.35 & -0.1 & 1.21 & $\begin{array}{l}\text { skewed, Leptokurtic } \\
\text { Coarse sand, Moderately sorted, Fine }\end{array}$ \\
\hline $\mathrm{BD} 4 \mathrm{~A}(\mathrm{BM})$ & 0.73 & 0.76 & 0.21 & 0.96 & $\begin{array}{l}\text { skewed, Mesokurtic } \\
\text { Coarse sand, Moderately sorted, Fine }\end{array}$ \\
\hline $\mathrm{BD} 4 \mathrm{~B}(\mathrm{WL})$ & 0.77 & 0.72 & 0.19 & 0.98 & skewed, Mesokurtic. \\
\hline
\end{tabular}

The result of grain size analysis of samples from Badagry beach is presented in table 1 . The results show that the sediments are medium grained sand, moderately well sorted, finely skewed and mesokurtic. The mean which is a reflection of the overall size of the sediments has an average value of $1.10 \Phi$; (medium sand), the standard deviation has an average value of
$0.51 \Phi$ (moderately well sorted), skewness values ranged from $-0.10 \Phi$ to $0.27 \Phi$ (coarse to fine skewed) while kurtosis values lies between $0.96 \Phi$ and $1.39 \Phi$ (mesokurtic and leptokurtic). The plot of individual particle size against phi size showed uni-modal peaks and this suggests a single source of sediment supply to the Badagry beach. 
Table 2: Granulumetric Analysis of Takwa Bay Beach Sediment.

\begin{tabular}{|c|c|c|c|c|c|}
\hline Sample No & Mean & $\begin{array}{l}\text { Standard } \\
\text { deviation }\end{array}$ & Skewness & Kurtosis & Description \\
\hline TK $1 \mathrm{~A}(\mathrm{BM})$ & 2.27 & 0.33 & -0.001 & 1.05 & $\begin{array}{l}\text { Fine sand, Very well sorted, Near } \\
\text { symmetrical, Mesokurtic. }\end{array}$ \\
\hline TK1 B(WL) & 2.11 & 0.44 & 0.003 & 1.09 & $\begin{array}{l}\text { Fine sand, Well sorted, Near } \\
\text { symmetrical Mesokurtic. }\end{array}$ \\
\hline TK2 A(BM) & 2.29 & 0.29 & -0.006 & 1.07 & $\begin{array}{l}\text { Fine sand, very well sorted, Near } \\
\text { symmetrical Mesokurtic. } \\
\text { Fine sand Well sorted. Near }\end{array}$ \\
\hline TK 2B(WL) & 2.24 & 0.3 & 0.006 & 0.9 & $\begin{array}{l}\text { symmetrical, Mesokurtic. } \\
\text { Fine sand, Very well sorted, Coarse }\end{array}$ \\
\hline TK 3A(BM) & 2.38 & 0.27 & -0.1 & 1.11 & $\begin{array}{l}\text { skewed, Leptokurtic. } \\
\text { Fine sand, Well sorted, Near }\end{array}$ \\
\hline TK3 B(WL) & 2.18 & 0.43 & 0.001 & 0.9 & $\begin{array}{l}\text { symmetrical, Mesokurtic. } \\
\text { Fine sand Very well sorted Near }\end{array}$ \\
\hline TK4 A(BM) & 2.42 & 0.29 & -0.08 & 1.08 & $\begin{array}{l}\text { symmetrical Mesokurtic. } \\
\text { Fine sand, Well sorted, }\end{array}$ \\
\hline TK 4B(WL) & 2.1 & 0.41 & -0.05 & 1.03 & symmetrical, Mesokurtic. \\
\hline
\end{tabular}

The granulometric analysis results of sediments from Takwa bay is shown in table 2 . The grain size is fine sand, very well sorted, near symmetrical and mesokurtic. The average mean value is $2.25 \Phi$ (fine sand), standard deviation $0.34 \Phi$ (very well sorted), skewness values ranged from -0.006 to 0.001 (near symmetrical to coarse skewed). Kurtosis values are between 0.9 and 1.1 (Mesokurtic and Leptokurtic). The plot of phi size against the individual particle size showed uni-modal peaks. This suggests a single source of sediment to the Takwa bay beach sand.

Table 3: Granulometric Analysis of Alpha Beach Sediments

\begin{tabular}{|c|c|c|c|c|c|}
\hline Sample No & Mean & $\begin{array}{l}\text { Standard } \\
\text { Deviation }\end{array}$ & Skewness & Kurtosis & Description \\
\hline AlF1A(BM) & 1.54 & 0.53 & 0.19 & 1.09 & $\begin{array}{l}\text { Medium sand, Moderately well sorted, } \\
\text { fine skewed, Mesokurtic. } \\
\text { Medium sand, Moderately well sorted, }\end{array}$ \\
\hline ALF1B(WL) & 1.39 & 0.59 & 0.09 & 1.03 & $\begin{array}{l}\text { Near symmetrical, Mesokurtic } \\
\text { Medium sand, Moderately sorted, Fine }\end{array}$ \\
\hline ALF2A(BM) & 1.33 & 0.77 & 0.13 & 0.94 & $\begin{array}{l}\text { skewed, Mesokurtic } \\
\text { Coarse sand, Moderately well sorted, }\end{array}$ \\
\hline ALF2B(WL) & 0.93 & 0.66 & 0.1 & 0.93 & $\begin{array}{l}\text { Fine skewed, Mesokurtic. } \\
\text { Medium sand, Moderately well sorted, }\end{array}$ \\
\hline ALF3A BM) & 1.11 & 0.66 & 0.12 & 0.89 & $\begin{array}{l}\text { Fine skewed, Platykurtic } \\
\text { Medium sand, Moderately well sorted, }\end{array}$ \\
\hline ALF3B(WL) & 1.02 & 0.64 & 0.06 & 1.12 & $\begin{array}{l}\text { Near symmetrical, Leptokurtic. } \\
\text { Medium sand, Moderately sorted, }\end{array}$ \\
\hline ALF4A(BM) & 1.02 & 0.85 & -0.1 & 0.76 & $\begin{array}{l}\text { Coarse skewed, Platykurtic. } \\
\text { Coarse sand, Moderately sorted, Near }\end{array}$ \\
\hline ALF4B(WL) & 0.83 & 0.8 & -0.02 & 0.93 & symmetrical, Mesokurtic. \\
\hline
\end{tabular}

The sediment distribution range between medium to coarse sand, moderate to well sorted, finely skewed with mesokurtic distribution (Table 3). The mean, which is a reflection of the overall size of the sediment, has values ranging from $(0.83 \Phi$ to $1.54 \Phi)$ which represents medium-coarse grained sand while the standard deviation which is a measure of the sorting has values ranging from $(0.53 \Phi$ to $0.85 \Phi)$ that represents moderate to well sorted. Skewness values range from ($0.02 \Phi$ to $0.19 \Phi)$ while kurtosis value lies between $(0.76 \Phi$ and $1.12 \Phi)$. The plot of individual particle size against phi size for the various samples shows bi-modal peaks, which suggests more than one source of sediment supply to the Alpha beach sand.

The granulometric analysis result of Eleko beach sediments is shown in table 4 . The result show that the grain size distribution of Eleko beach sediments ranged from moderately sorted sands to coarse grained sands, fine skewed with Mesokurtic distribution. The mean has an average value of $0.56 \Phi$ (coarse sand), while the average standard deviation is $0.83 \Phi$ (moderately sorted). The plot of phi size against individual particle size for the various samples showed a uni-modal grain size composition and this suggests a possible single source of sediment supply to the beach. 


\begin{tabular}{|c|c|c|c|c|c|}
\hline Sample No & Mean & $\begin{array}{l}\text { Standard } \\
\text { deviation }\end{array}$ & Skewness & Kurtosis & Description \\
\hline LK1A(BM) & 0.55 & 0.74 & 0.03 & 0.91 & $\begin{array}{l}\text { Coarse sand, Moderately sorted, Near } \\
\text { symmetrical, Mesokurtic } \\
\text { Coarse sand, Moderately sorted, Coarse }\end{array}$ \\
\hline LK 1B(WL) & 0.33 & 0.92 & -0.105 & 0.72 & $\begin{array}{l}\text { skewed, Platykurtic. } \\
\text { Coarse sand, Moderately sorted, Near }\end{array}$ \\
\hline LK 2A(BM) & 0.81 & 0.75 & 0.06 & 0.99 & $\begin{array}{l}\text { symmetrical Mesokurtic. } \\
\text { Coarse sand, Moderately sorted, Fine }\end{array}$ \\
\hline LK 2B(WL) & 0.66 & 0.97 & 0.17 & 0.76 & $\begin{array}{l}\text { skewed, Platykurtic. } \\
\text { Coarse sand, Moderately sorted, Fine }\end{array}$ \\
\hline LK 3A(BM) & 0.9 & 0.75 & 0.17 & 1.04 & $\begin{array}{l}\text { skewed, Mesokurtic. } \\
\text { Coarse sand, Moderately sorted, Strongly }\end{array}$ \\
\hline LK 3B(WL) & 0.01 & 0.89 & -0.34 & 0.9 & $\begin{array}{l}\text { Coarse skewed, Mesokurtic. } \\
\text { Medium sand, Moderately well sorted, }\end{array}$ \\
\hline LK 4A(BM) & 1.18 & 0.64 & 0.1 & 1.23 & $\begin{array}{l}\text { Fine skewed, Leptokurtic. } \\
\text { Coarse sand, Poorly sorted, Strongly }\end{array}$ \\
\hline LK 4B(WL) & -0.05 & 1.02 & -0.65 & 0.78 & coarse skewed, Platykurtic. \\
\hline
\end{tabular}

\section{CONCLUSION}

The grain size distribution closely defines the energy level of the wave processes. Badagry and Alpha beaches are of medium grain size distribution with average mean value of $(1.10 \Phi$ to $1.14 \Phi$ respectively); Eleko beach sediment is coarsely grained with an average mean value of $(0.56 \Phi)$ while Takwa Bay beach sediments are fine grained and very well sorted with average mean value of $(2.25 \Phi$.) From this, we can deduce that Eleko beach sediments are deposited in a high energy condition and less vulnerable to erosion followed by Badagry and Alpha beaches which are deposited in a moderate energy condition and then Takwa Bay beach sediments which are deposited in a low energy condition and more vulnerable to erosion. For the effective management of erosion along the barrier bar coastal system, the grain size distributions of the sediments have to be appreciated. Hence the result of this study will be useful for the understanding of the sedimentary processes along the barrier bar coastal system. This study and other ocean dynamic studies will be needed to comprehend the regional sedimentary processes necessary for planning and decision making of the coastal projects along.

\section{ACKNOWLEDGEMENT}

The support by members of staff of Marine Geology Department during the field work is appreciated. The authors acknowledge Prof Awosika, DR Adegbie and DR Regina Folorunsho for their useful suggestion and remarks.

\section{REFERENCES}

Anita, E. E., 1993. Preliminary assessment of the impact of erosion along the Nigeria shoreline NIOMR Tech paper (13): 17.

Allen, J. R. L., 1965a. Late Quaternary Niger Delta and adjacent areas: Sedimentary environments and Lithofacies. AAPG Bull. 49, 547-600.

Bernard, H. A., Leblance, R. J and Major, C. F., 1962. Recent and Pleistocene history of Southeast Texas. Houston Geol. S oc. 175-224.

Folk, R. H., 1966. A review of grain size parameters sedimentology $6,73-93$.

Freidman, G. M., 1961. Distinction between dune beach and River sand from textural characteristics. Journal of sedimentary petrology 31,514 .

Hoyt, J. H., 1967. Barrier Island formation Geol.soc. Amer. Bull., 78, 1125-1136.

Ibe, A. C and Awosika, L. F., 1988. Sedimentology of beaches of barrier bar complexes in Nigeria. NIOMR Tech paper (28): 18.

Ibe, A. C., Awosika, L. F and Ibe, C. E., 1993. Factors responsible for varying granulometric characteristics of sediments from the western Nigeria coastline. Coastline of western African coastal zone 93. Ed. Larry Awosika, Chidi lbe and Peter schnoder. Pub American association of civil engineers.

Li, Z and Komar, P. D., 1992. Longshore grain sorting and beach placer formation journal of sedimentary petrology 62, 429-441. 


\section{APPENDICES}
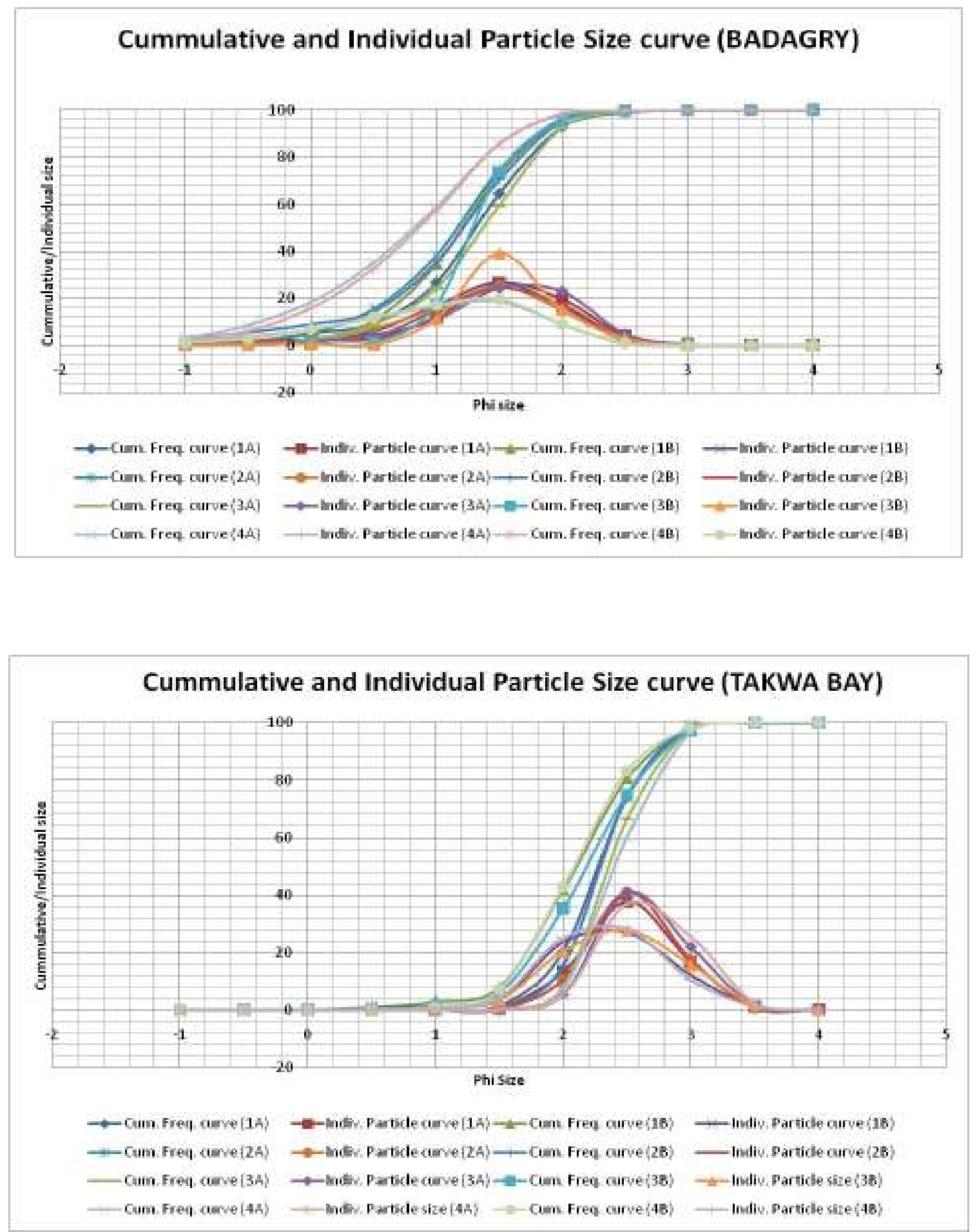


\section{Cummulative and Individual Particle Size curve (ALPHA)}

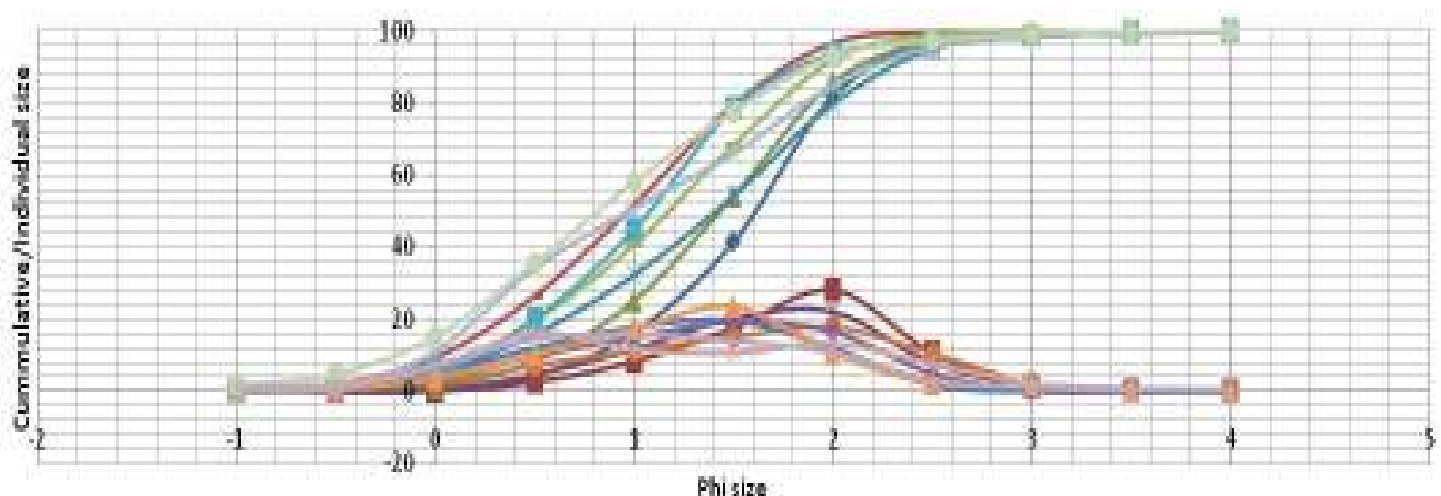

Phisize

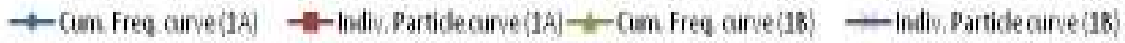

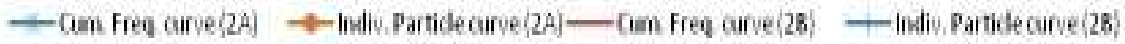

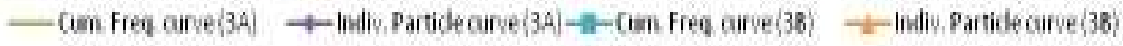

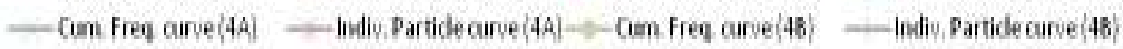

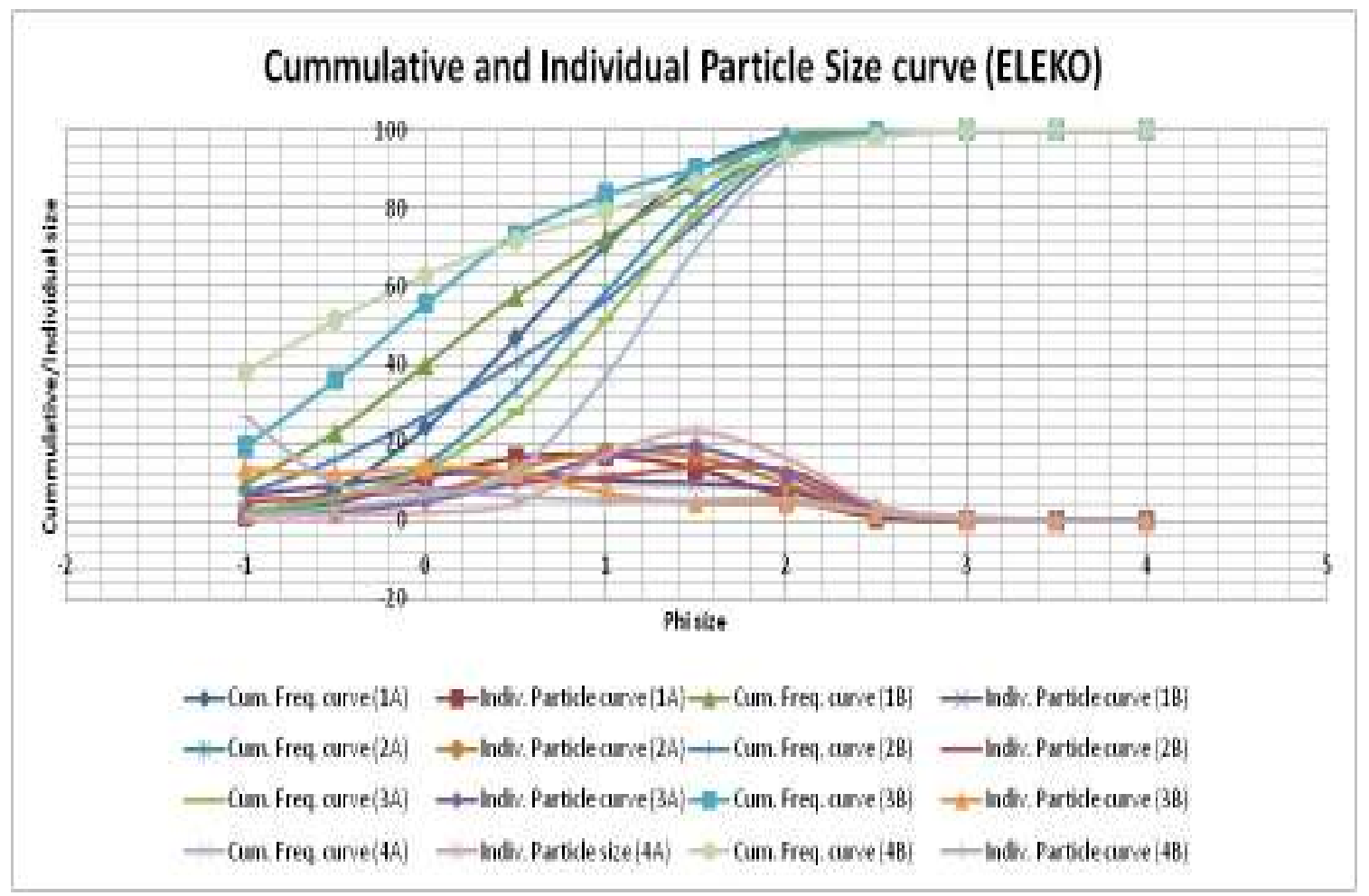

